\title{
The Factors Impact on Internet Banking Adoption with Special Reference to Kurunegla District
}

\author{
R.P.H.D. Chandrasiri ${ }^{1} \&$ T.K. Karandakatiya ${ }^{2}$ \\ ${ }^{1,2}$ Department of Business Management \\ Faculty of Business Studies \& Finance \\ Wayamba University of Sri Lanka \\ Kuliyapitiya \\ SRI LANKA \\ hansakadhilchan05@gmail.com ${ }^{1}$, thusithakk@wyb.ac.lk ${ }^{2}$
}

\begin{abstract}
The emerging technology has made a phenomenal growth of the Internet which has changed the pattern of organizations performing their business with customers. The banking industry could not survive without accepting the growth in technology. In order to gain competitive advantage, the banks have introduced internet banking services. However, the customers have not adopted this concept as the banks expected. Literature available in that issue shows a wide range of variations in the understanding of internet banking adoption in different context confirming the inherent nature of such behavioural issues. In the Sri Lankan context as well such variations is available and a shortage of knowledge is available on the impact of factors affecting the internet banking adoption by bank customers. Consequently, the purpose of this study is to identify the factors which impact on internet banking adoption in Kurunegala district having the third largest population density in Sri Lanka. Available research in the Sri Lankan context in this regard is mainly focused on western province. A conceptual model was developed with the support of available literature. Structured questionnaire was administered to collect data from 200 Internet banking customers in Kurunegala district through convenience sampling. Descriptive statistics, correlation analysis and regression analysis are used in the data analysis. This study found that perceived ease of use, perceived usefulness, security, perceived risk and social influence have impact on internet banking adoption in Kurunegala district. Further results of multiple regression analysis reveal that most significant predictor was social influence. This study recommends that banks should use awareness programs to increase social influence and provide knowledge to the customers regarding the usefulness of internet banking service than using other banking channels such as mobile and traditional banking.
\end{abstract}

Keywords: Perceived Ease of Use, Perceived Risk, Perceived Usefulness, Security, Social Influence, Internet Banking Adoption 


\section{INTRODUCTION}

Internet banking is one of new trends that banks increasingly respond (Fernando, 2016). The Internet banking service can play a major role in banking industry which makes customers easier to perform their day to day banking transactions with finger tips without visiting to the premises of banks. As a matter of fact, internet banking service in banking industry is a very fast-growing trend in developed countries (Yeow, 2010). Since the Internet banking service is fast growing and expanding, the low usage rate on internet banking service still exist in the Sri-Lankan banking industry (Kariyawasam \& Jayasiri, 2016). Banks try to improve customer adoption in internet banking but customers do not use it in a sufficient way. Although few studies were carried out in order to address that issue, a mix of results can be seen regarding the causes or factors affecting the internet banking adoption in the Sri Lankan context (Dasanayaka \& Mahesh, 2016; Mangalee, \& Wijenayake, 2017). Hence, still there is a gap in our knowledge on the factors that may have impact on the adoption of internet banking service in specific context like Kurunegala district. Further such understanding would be highly useful in promoting internet banking service and there by retaining valuable customers. As well as it would provide valuable knowledge and information to banks, service developers and software engineers to enhance customers' intention to use internet banking service in the future.
Therefore, the aim of this research is to identify the determinants of customer adoption of internet banking and their impact on internet banking adoption with special focus to Kurunegala district.

\section{Internet banking}

Internet banking is, "to give customers access to their bank accounts via a web site and to enable them to enact certain transactions on their accounts, given compliance with stringent security checks" (Essinger,1999). Internet Banking allows customers to conduct financial transactions on a secure website operated by their retail or virtual bank, credit union or building society. This is usually conducted through a personal computer that connects to a banking web site via the Internet. Internet Banking can also be conducted via wireless technology through both personal digital Assistants and cellular phones.

Ability to transfer money between accounts, bill payments, pawning inquiries, loan requesting, view statements and perform other financial transactions over the Internet. Internet banking as the delivery of banks' information and services by banks to customers via different delivery platforms that can be used with different terminal devices such as a personal computer and a mobile phone with browser or desktop software, telephone or digital television (Eriksson, 2007). 


\section{Customer adoption of internet banking}

Individual's decision to become a regular user of a product which may be an innovation in form of a good, service or idea or consumer adoption is the process of consumers use to determine whether or not to adopt an innovation. Among the different models that have proposed, in the field of IT adoption and usage, the frameworks of dominating literature are such as the Technology Acceptance Model (TAM) by (Davis, 1986) adapted from the Theory of Reasoned Action (TRA) (Ajzen \& Fishbein, 1980) appears to be the most widely accepted among information systems related researchers.

According to Rogers (1995) the theory of Diffusion of innovation was to mention the foundation for conducting research on innovation acceptance and adoption. Rogers did diffusion studies and finally build "Diffusion of Innovation" theory for the adoption of innovations through individuals and organization. The basic Technology Acceptance model tested and included two important variables like perceived usefulness and perceived ease of use.

The external variables in the TAM are influenced to the belief of the person towards a System. Venkatesh and Davis (1996) formed the final version of TAM (See for example, Venkatesh,2000).

\section{Factors Impact on Internet banking adoption}

The researcher discovered several factors that impact on internet banking adoption in terms of perceived usefulness, perceived ease of use, security, perceived risk, social influence.

\section{Perceived usefulness}

Perceived usefulness is one of the critical elements of TAM. There are various number of definitions have been given for the term usefulness. According to the earlier studies, suggested that there is a positive relationship between Perceived usefulness and intention to use (Wang,et al, 2003). Using a particular system will enhance one's job performance (Davis-1989).

The perceived usefulness with the adoption of information technology has a positive effect (Safeena, Date and Kammai, 2011).Therefore; it is highly predictable that people use Internet banking services because they find it useful. The degree to which a person believes that using a particular system would enhance their performance" (Dholakia \& Dholakia, 2004). It is clear that new technology should be cost effective than the prevailing method in order to make a choice to adopt new technology. (Davis,Bagozzi and Warnshaw, 1989). 


\section{Perceived ease of use}

Perceived ease of use means the degree to which an individual believes/ thinks that using a selected system would be free from mental and physical efforts. Davis (1986) suggested that the Technology Acceptance Model (TAM) shows the power of ease of use in technology adoption. Specifically, Davis defined ease of use as the degree to which a person believes that using a particular service would be free of effort (Davis, 1989). According to Venkatesh (2000), the perception of use is an important determinant of user's intention to use something that related to the Internet applications. Base on Eriksson et al., (2005) "ease of use" is one of the main determinants of popularity of usage. They reviewed the ease of use as one of the determinants that should not neglect its relationship with technology anxiety. Thus, Adoption of Internet banking is more likely to occur if the process of usage is easy for customers.

\section{Security}

Security is one of the very valuable factors in determining the intention to use of Internet banking. Internet banking faced with this particular issue and it leads to reluctance of Internet banking usage. People still have a weak understanding of managing the use of e-banking facilities at the best conduct of practice (Pikkarrainen et al., 2004).One of the major influencing factors around the establishment and use of new technologies for financial transactions is that of security and trust (Brown et al., 2001).The need for security of personal details and financial information is therefore critical to the success of Internet banking.

\section{Perceived risk}

Perceived Risk refers to the degree of uncertainty about the benefits of Internet banking (Priya, Gandhi, \& Shaikh, 2016). Luo et al. (2010) mention that there were four dimensions including in perceived risk.

\section{Social Influence}

Social influence also appears to have an impact on perceptions about the innovation in voluntary settings (Venkatesh, Morris, Davis \& Davis, 2003). That is social networks and position of the adopter in them has a strong influence on adoption. Furthermore, Social Influence could study from personal influence. According to Baines et al. (2013) defines, Social Influence is a phenomenon-explaining customer imitating behavior studied from social learning.

\section{Research Framework}

Based on the literature, the following conceptual framework has been developed. 


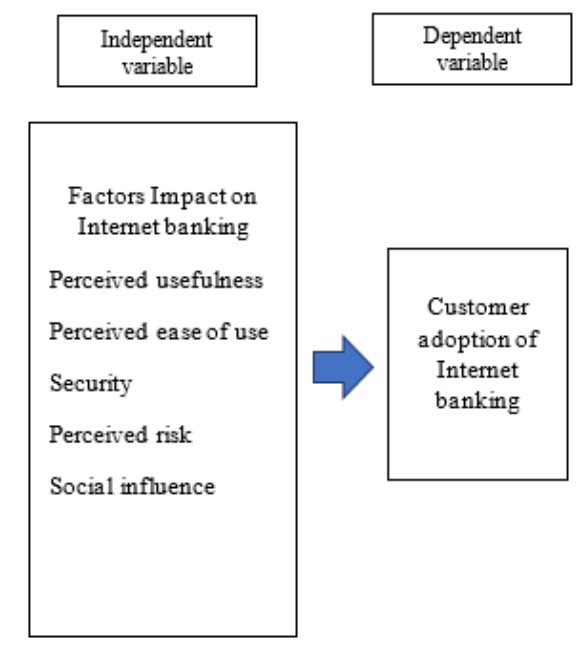

Figure 1. Conceptual Framework

Based on the research framework, following hypothesis were developed to answer the research questions.

$\mathrm{H}_{1}$ : There is a significant relationship between perceived usefulness and adoption of internet banking in Kurunegala district in Sri Lanka.

$\mathrm{H}_{2}$ : There is a significant impact of perceived ease of use on adoption of internet banking in Kurunegala district in Sri Lanka.

$\mathrm{H}_{3}$ : There is a significant relationship between perceived ease of use and adoption of internet banking in Kurunegala district in Sri Lanka.

$\mathrm{H}_{4}$ : There is a significant impact of perceived usefulness on adoption of Internet banking in Kurunegala district in Sri Lanka.

$\mathrm{H}_{5}$ : There is a significant relationship between security and adoption of internet banking in Kurunegala district in Sri Lanka.
$\mathrm{H}_{6}$ : There is a significant impact of security on adoption of Internet banking in Kurunegala district in Sri Lanka.

$\mathrm{H}_{7}$ : There is a significant relationship between perceived risk and adoption of internet banking in Kurunegala district in Sri Lanka.

$\mathrm{H}_{8}$ : There is a significant impact of perceived risk on adoption of Internet banking in Kurunegala district in Sri Lanka.

$\mathrm{H}_{9}$ : There is a significant relationship between social influence and adoption of internet banking in Kurunegala district in Sri Lanka.

$\mathrm{H}_{10}$ : There is a significant impact of social influence on adoption of internet banking in Kurunegala district in Sri Lanka.

\section{METHODS}

\section{Sample}

The population of this study is the banking customers in the Kurunegala district. For this study, the researcher was unable to consider a random sampling technique due to the absence of a sample frame for research purposes in the industry. Consequently, convenience sampling method was employed for the purpose of study. Convenience sampling (also known as availability sampling) is a specific type of non-probability sampling method that relies on data collection from population members who are conveniently available to participate in study. The researcher selected 200 internet banking customers in the Kurunegala district 
using convenience sampling technique for the study.

\section{Instrumentation}

Variables considered in the model were measured using standard instruments (Venkate- sh \& Zang, 2010; Aboelmaged \& Gebba, 2013; Luarn \& Lin, 2005; Yu, S.2009; Priya, Gandhi \& Shaikh 2018; Chiu, Bool \& Chiu, 2017). For this research, both primary data sources and secondary data sources were used in the data collection. Form of questionnaire is used as the main instrument for data collection. The survey questionnaire comprised two sections as part A and part B. Part A of the questionnaire contained questions relating to demographic factors such as gender, age, education qualification and so on. Part $\mathrm{B}$ included questions relating to five independent variables and the dependent variable.

\section{RESULTS}

The data analysis of this research conducted through SPSS version 21 . Mainly this research used the Pearson correlation and the regression analysis. Reliability analysis also tested to assure the reliability of the questionnaire. 200 questionnaires were returned marking $76 \%$ response rate. Necessary action has made with regard to the incomplete questionnaires and normality test was conducted and assured that data were normally distributed.

Initially, the researcher analyzed the demographic data to get an idea regarding the respondent profile. Where, the age, gender, educational qualifications, income level of respondents were analyzed. The survey consisted with 130 male respondents and 70 female, where majority of them were around the 2635 age group. Most of respondents were work at private sector with diploma level qualification. Most of the people used internet banking service for period of 1-3 years and bill payment facility was the most preferred facility enjoyed by the respondents

Reliability test is used to assess the inter item internal consistency of instruments. According to the Cronbatch's alpha value, perceived usefulness, perceived ease of use, security, perceived risk, had good reliability because the Cronbatch's alpha value is ranged from 0.70 to 0.80 . And the values of social influence, and internet banking adoption had very good reliability because alpha value is ranged in between $0.80-0.90$. Therefore, reliability of all the instruments were at accepted level.

According to the mean values of perceived ease of use, perceived risk and social influence were 3.8760 , 3.7775 and 3.6263 respectively and these values were neared to the 'agree' side in the five-point Likert scale. Mean values of perceived usefulness and security were 4.0240 and 4.2888 respectively and are headed to the strongly agree side of the Five-point Likert scale. However, all the mean values were represented by positive side. Standard deviation of perceived usefulness, perceived ease of use, security, perceived risk and social influence were 0.4829, 0.46960, 
$0.55144, \quad 0.40629, \quad$ and $\quad 0.6072$ respectively

The Pearson's Correlation is used to analyze the relationship between independent variables and dependent variable. To support the hypothesis, the p-value of the r-path coefficient should be significant at the 0.05 level" $\mathrm{Yu}$ (2009). Considering the Pearson Correlation value, it can be identified the strength of the relationship. If Pearson Correlation value is positive it indicates that there is a positive relationship between two variables, if it is negative it indicates negative relationship between variables. According to the analysis all the independent variables namely perceived usefulness, perceived ease of use, security, perceived risk and social influence showed positive relationship with the internet banking adoption with marking highest relationship by the variable of social influence (See table 2).

Table 1. Regression Analysis

\begin{tabular}{|l|l|l|l|l|}
\hline Model & $\mathrm{R}$ & $\mathrm{R}^{2}$ & $\begin{array}{c}\text { Adjusted } \\
\mathrm{R} \text { square }\end{array}$ & $\begin{array}{c}\text { Std. } \\
\text { Error of } \\
\text { the } \\
\text { estimate }\end{array}$ \\
\hline 1 & .670 & .449 & .435 & .6275 \\
\hline
\end{tabular}

There is $.670 \mathrm{R}$ value. The value of $\left(\mathrm{R}^{2}\right)$ of the regression model was 0.449 which means $44.9 \%$ of the total variance in the internet banking adoption is explained by the model.

In regression analysis, unstandardized coefficient indicated that how much the dependent variable varies with an independent variable when all other independent variables are held constant and following table 2 showed the outcome with regard to the hypothesis testing.

Table 2. Summery of Hypotheses Testing

\begin{tabular}{|c|c|}
\hline Hypotheses & $\begin{array}{c}\text { Accepted / } \\
\text { Rejected }\end{array}$ \\
\hline $\begin{array}{l}\text { H1: There is a } \\
\text { significant relationship } \\
\text { between perceived } \\
\text { usefulness and adoption } \\
\text { of internet banking in } \\
\text { Kurunegala district in } \\
\text { Sri Lanka. } \\
(\mathrm{r}=0.376, \mathrm{p}<0.01) \text {. }\end{array}$ & Accepted \\
\hline $\begin{array}{l}\mathrm{H} 2 \text { : There is a } \\
\text { significant Impact of } \\
\text { perceived ease of use on } \\
\text { adoption of internet } \\
\text { banking in Kurunegala } \\
\text { district in Sri } \\
\text { Lanka. }(\beta=0.594, \mathrm{p}<0.01)\end{array}$ & Accepted \\
\hline $\begin{array}{l}\text { H3: There is a } \\
\text { significant relationship } \\
\text { between perceived ease } \\
\text { of use and adoption of } \\
\text { internet banking in } \\
\text { Kurunegala district in } \\
\text { Sri Lanka. } \\
(\mathrm{r}=0.356, \mathrm{p}<0.01) \text {. }\end{array}$ & Accepted \\
\hline $\begin{array}{l}\text { H4: There is a } \\
\text { significant Impact of } \\
\text { perceived usefulness on } \\
\text { adoption of Internet } \\
\text { banking in Kurunegala } \\
\text { district in SriLanka. ( } \beta \\
=0.199, \mathrm{p}>0.01) \text {. }\end{array}$ & Rejected \\
\hline
\end{tabular}




\begin{tabular}{|c|c|}
\hline $\begin{array}{l}\text { H5: There is a } \\
\text { significant relationship } \\
\text { between security and } \\
\text { adoption of internet } \\
\text { banking in Kurunegala } \\
\text { district in Sri Lanka. } \\
(\mathrm{r}=0.378, \mathrm{p}<0.01) \text {. }\end{array}$ & Accepted \\
\hline $\begin{array}{l}\text { H6: There is a } \\
\text { significant Impact of } \\
\text { security on adoption of } \\
\text { Internet banking in } \\
\text { Kurunegala district in } \\
\text { SriLanka. } \\
(\beta=0.312, p<0.01) .\end{array}$ & Accepted \\
\hline $\begin{array}{l}\text { H7: There is a } \\
\text { significant relationship } \\
\text { between perceived risk } \\
\text { and adoption of internet } \\
\text { banking in Kurunegala } \\
\text { district in Sri Lanka. } \\
(\mathrm{r}=0.379, \mathrm{p}<0.01) \text {. }\end{array}$ & Accepted \\
\hline $\begin{array}{l}\text { H8: There is a } \\
\text { significant Impact of } \\
\text { perceived risk on } \\
\text { adoption of Internet } \\
\text { banking in Kurunegala } \\
\text { district in Sri Lanka. } \\
(\beta=0.372, p>0.01) \text {. }\end{array}$ & Rejected \\
\hline $\begin{array}{l}\text { H9: There is a } \\
\text { significant relationship } \\
\text { between social influence } \\
\text { and adoption of internet } \\
\text { banking in Kurunegala } \\
\text { district in SriLanka. } \\
(\mathrm{r}=0.463, \mathrm{p}<0.01) \text {. }\end{array}$ & Accepted \\
\hline $\begin{array}{l}\text { H10: There is a } \\
\text { significant Impact of }\end{array}$ & Accepted \\
\hline
\end{tabular}

\begin{tabular}{|l|}
\hline social influence on \\
adoption of internet \\
banking in Kurunegala \\
district in SriLanka. $(\beta$ \\
$=0.365, \mathrm{p}<0.01)$.
\end{tabular}

\section{DISCUSSIONS}

The research study was conducted to identify factors impact on internet banking adoption with special reference to the Kurunegala district. The results showed that there is positive relationship between perceived usefulness and internet banking adoption, between perceived ease of use and internet banking adoption, between security and internet banking adoption, between perceived risk and internet banking adoption, between social influence and internet banking adoption.

According to the regression analysis, perceived ease of use, security and social influence were significant and, perceived usefulness and perceived risks were insignificant. Findings of Mangalee, and Wijenayake (2017) substantiate the findings of the present study. However, Brown.et al. (2001) point out perceived risk is the most influential factor affecting the internet banking adoption. Chiu, et al (2017) also point out that security and trust are the most influential factors affecting the internet banking adoption. Dasanayaka \& Mahesh.(2016) as well substantiate the same. However, the present study has a deviation from their findings with respect to the perceived risk. 
Consequently, mix results indicate that internet banking adoption is dynamic in nature and more general model is less effective.

\section{CONCLUSION}

This study identified certain factors that influence in adoption of Internet banking in Kurunegala district. In the present, consider only five variables in terms of perceived ease of use, perceived usefulness, security, perceived risk and social influence. However, there are various factors influencing to the adoption of Internet banking. The future researchers can implement new studies through other variables (compatibility, structured assurance, service quality, users' experience) not covered in this study. According to the outcome of this research, it showed that perceived usefulness, perceived ease of use, perceived risk, security and social influence have relationship with the internet banking adoption and among them except perceived usefulness and perceived risk, other factors showed significant impact on internet banking adoption.

Banks can use following options to attract or to adopt customers towards the internet banking by focusing much on most significant factors which were identified. Business promotion officers in the bank can provide announcement about the usefulness and ease of use of the internet banking service. Banks can distribute leaflets about the usefulness and ease of use in internet banking service around the Kurunegala district. Bank can play video clips in front of the bank premises to get customer attraction towards the internet banking. Banks should use announcement campaigns and awareness programs regarding internet banking service. This will help to increase social awareness and increase social influence for customer to adopt this service. Internet banking service system should contain separate assistance service section to manage any problem that can be happened. It will be most important for the customers to solve their problems in case of problem. As well as banks should get actions to increase accessibility of internet banking service in everywhere at any time. Banks should focus on reducing the gap between customer's expectations and their satisfaction when considering the future internet banking service. Proper steps should be taken to make the internet banking service more efficient and user friendly

The present study can be further extended in future research endeavors by expanding to banking industry throughout the country. Additional empirical research seems to be required to identify and examine factors that may impact on customers' adoption of internet banking services as findings indicated general model of adoption of internet banking is less effective.

\section{REFERENCES}

Aboelmaged, M.; Gebba, T.R.( 2013). Mobile Banking Adoption: An Examination of Technology 
Acceptance Model and Theory of Planned Behavior. International Journal of Business Research. 2(1). pp.35-50.

Ajzen, I., \& Fishbein, M. (1980). Understanding attitudes and predicting social behavior. Englewood Cliffs, NJ: PrenticeHall.

Baines, P., Fill, C., \& Page, K. (2013). Essentials of marketing. Oxford: Oxford Univ- ersity Press.

Brown, I., Cajee, Z., Davies, D. and Stroebel, S. (2001), "Cell phone banking: Predictors of adoption in South Africa- An exploratory study", International Journal of Information Management, 23(5), pp. 381-394.

Chiu, J.L., Bool, N.C. and Chiu, C.L. (2017), "Challenges and factors influencing initial trust and behavioral intention to use mobile banking services in the Philippines", Asia Pacific Journal of Innovation and Entrepreneurship, 11 (2), pp. 246278.

Dasanayaka, S \& Mahesh D. D.(2016). Factors affecting the adoption of internet banking in Sri Lanka from perspectives of personnel customers. Conference Proceedings, pp.22-26.

Davis, F.D. (1986). A technology acceptance model for empirically testing new end-user information systems: theory and results. Doctoral dissertation. MIT Sloan
School of Ma- nagement, Cambridge, MA.

Davis, F.D. (1989).Perceived Usefulness, Perceived Ease of Use, and User Acceptance of Information Technology. MIS Quarterly.13, (3). pp. 319-340.

Davis, F.D.; Bagozzi, R. P.; Warshaw, P.R.(1989). User Acceptance of Computer Technology: A Comparison of Two. Management Science. 35(8). pp. 982.

Dholakia, R. R., \& Dholakia, N. (2004). Mobility and markets: emerging outlines of $\mathrm{m}$ commerce. Journal of Business Research, 57(12), pp.1391-1396

Essinger, J. (1999). "The Virtual Banking Revolution".The Customer, the Bank and the Future.1st ed., International Thomson Business Press, London, UK.

Fernando, K.C.L. 2016. New trends of online banking in Sri Lanka. Arthikavidya, Journal of Economics Students' Society, Economics Student Society, Department of Economics, University of Kelaniya, Sri Lanka. 11(1).pp. 172 -184.

Hogarth, J., 2004. the adoption of electronic banking technologies by US customers. International Journal of bank marketing. 1(9).

Kariyawasam,. J. \& Jayasiri, U.K. (2016) Awareness and usage of 
internet banking facilities in Sri Lanka .International Journal of Scientific Research and Innovative Technology 3(6). pp.173-190.

Eriksson, $\mathrm{K} \quad \& \quad$ Nilsson,D (2007).Determinants of the continued use of self-service technology: The case of Internet banking.

Technovation 27(4).pp.159-167

Lee, M. C., 2008. Factors Influencing the adoption of internet banking ; an integration of TAM and TPB. "Go to Electronic Commerce Research and Applications on Science Direct" Electronic Commerce Research and Applications .8(3).pp.130-141.

Luarn, P. \& Lin, H. H., 2005. Toward An Understanding Of The Behavioural Intention To Use Mobile Banking. Computers in Human Behaviour. 21, pp. 873891.

Luo, X., Li, H., Zhang, J., \& Shim, J.P. (2010). Examining multidimensional trust and multifaceted risk in initial acceptance of emerging technologies: An empirical study of mobile banking services. Decision Support System, 49(2), pp.222-234.

Mangalee, J.D.C. and Wijenayake, S.I. (2017).The Factors Influencing on Internet Banking Adoption in Sri Lanka.2nd Student Research Conference on Marketing (SRCM), Department of Marketing Management, University of Kelaniya, Kelaniya. pp.79.

Mattila, M., 2002. Factors affecting the adoption of Mobile Banking Service. Journal of Internet Banking and Commerce (JIBC).

Perera, A., 2018. the factors influencing on the customer adoption of internet banking. internatioanal journal of scientific and research publications. 8(2).pp.83-107.

Pikkarrainen, T., Pikkarrainen, K., Karjaluoto, H. and Pahnila, S. (2004). Consumer acceptance of online banking: an extension of the technology acceptance model. Internet Research, 14(3), pp.224235.

Priya, R.; Gandhi, A.; Shaikh, A.(2018). Mobile banking adoption in an emerging economy. Benchmark. International Journal.25, pp.743762.

Roger, E. M., (1995), Diffusion of Innovations, Fourth edition, New York: Free Press.

Safeena, R., Date, H. \& Kammani,A.(2011). Internet Banking Adoption in an Emerging Economy:Indian Consumer's Perspective. International Arab Journal of e-Technology, 2(1).pp.56-63.

Sekaran, U., 2016. research mathord for business A skill bulding 
approch .7th ed. USA:John Willey \& Sons.Inc.

Srivastava, R. K., 2007. Costomers perception on usege of internet banking.3(4).

Tiwari, R., Buse, S. \& Herstatt, C., 2006. Mobile Banking As Business Strategy:Impact Of Mobile Technologies On CustomerBehaviour And Its Implications For Banks. Technology and Innovation Management.

Venkatesh, V. \& Zhang, X., 2010. Unified theory of acceptance and use of technology: U.S. vs. China. Journal of Global Information Technology Management.13(1), pp. 5-27.

Venkatesh, V., 2000. Determinants of perceived ease of use: integrating control, intrinsic motivation, and emotion into the technology acceptance model.. Information Systems Research.11(4), pp. 342365.
Venkatesh, V.; Morris, M.G.; Davis, G.B.; Davis, F.D.(2003). User acceptance of information technology: Toward a unified view. MIS Quaterly,27,pp. 425478.

Wang, Y, Wang, Y, Lin, H \& Tang. (2003) T.,"Determinants of User Acceptance of Internet Banking: An Empirical Study," International Journal of Service Industry Management. 14(5), pp. 501-519.

Yeow, P.H.P. (2010).Internet Banking Adoption: Comparing Developed and Developing Countries. Journal of Computer Information Systems 51(1).pp.52.

Yu, S.(2009). Factors influencing the use of mobile banking: the case of SMS-based mobile banking. Auckland University of Technology 